\title{
Play Behaviors in Children during the COVID-19 Pandemic: A Review of the Literature
}

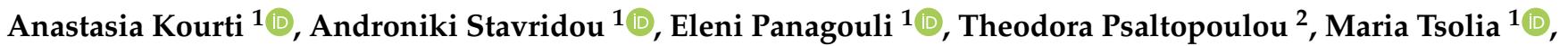 \\ Theodoros N. Sergentanis $1,2,+(\mathbb{D})$ and Artemis Tsitsika $1, *,+$ \\ 1 2nd Department of Pediatrics, “P. \& A. Kyriakou” Children's Hospital, School of Medicine, \\ National and Kapodistrian University of Athens, 11527 Athens, Greece; \\ anastasiakourti.ak@gmail.com (A.K.); stavroniki@hotmail.com (A.S.); eleni72000@yahoo.gr (E.P.); \\ mtsolia@med.uoa.gr (M.T.); tsergentanis@yahoo.gr (T.N.S.) \\ 2 Department of Clinical Therapeutics, "Alexandra" Hospital, School of Medicine, National and Kapodistrian \\ University of Athens, 11528 Athens, Greece; tpsaltop@med.uoa.gr \\ * Correspondence: info@youth-health.gr; Tel./Fax: +30-2107710824 \\ + The two authors equally contributed to this work.
}

check for updates

Citation: Kourti, A.; Stavridou, A.; Panagouli, E.; Psaltopoulou, T.; Tsolia, M.; Sergentanis, T.N.; Tsitsika, A. Play Behaviors in Children during the COVID-19 Pandemic: A Review of the Literature. Children 2021, 8, 706. https://doi.org/10.3390/children 8080706

Academic Editor: Johannes N. Van den Anker

Received: 11 July 2021

Accepted: 12 August 2021

Published: 17 August 2021

Publisher's Note: MDPI stays neutral with regard to jurisdictional claims in published maps and institutional affiliations.

Copyright: (c) 2021 by the authors. Licensee MDPI, Basel, Switzerland. This article is an open access article distributed under the terms and conditions of the Creative Commons Attribution (CC BY) license (https:/ / creativecommons.org/licenses/by/ $4.0 /)$.

\begin{abstract}
Play is a key factor for children's healthy psychological, emotional, social, and cognitive development. During the COVID-19 pandemic, it has been postulated that children's play was affected, not only regarding the time children spent playing but also in terms of the qualitative characteristics of play. The aim of this review was to investigate how children's play has changed during the COVID-19 pandemic. A review was conducted in the PubMed, Google Scholar, EMBASE, SCOPUS, ERIC, PsycInfo, and JSTOR databases up to 6 December 2020. Furthermore, references of eligible studies as well as of relevant articles were searched using a snowballing technique. The search retrieved 17 eligible studies, conducted in Europe and North America. In general, outdoor play was reduced during the pandemic; on the other hand, there was an increase in indoor play and in videogames-screen time. COVID-19 was present in children's pretend play. Children's play was a key contributor to children's mood and wellbeing. Furthermore, teachers were especially concerned about how children's play was affected during the lockdown measures. There is evidence that children's play habits were affected during the COVID-19 pandemic; further research is required, especially cross-culturally oriented.
\end{abstract}

Keywords: play; children; COVID-19; wellbeing; psychosocial development

\section{Introduction}

Play is a constitutional right for children, in accordance with the Convention on the Rights of the Child (Article 31), which highlights the "right to rest and leisure, to engage in play and recreational activities appropriate to the age of the child and to participate freely in cultural life and the arts" [1]. According to Eberle [2], "play is a roomy subject, broad in human experience, rich and various over time and place, and accommodating pursuits as diverse as peekaboo and party banter, sandlot baseball and contract bridge, scuba diving and Scrabble". In fact, play is considered a universal, intrinsic activity in children, present in every civilization, despite cultural differences [3]. The importance of play in children's social, emotional, and mental health has been argued by many specialists.

Play can be divided into three stages: embodiment, projection, and role play, collectively referred to as EPR [4]. The first one includes activities that are experienced through body (e.g., messy play, hopping, jumping); in the second stage, children use different media to express themselves (e.g., paper, colors, clay), while in the latter stage, children develop characters and stories through verbal and non-verbal means. Usually, the three stages of EPR are completed by the age of 7 years [5]. Different types of play could also be used regarding the means and manners (e.g., constructive play, fantasy play [5]), allowing children 
to explore the world, develop their skills, and enhance resilience. Moreover, through play, children can learn how to handle their fears and adopt adult behaviors as they grow older, while play is very beneficial for children's physical and cognitive development [6-13]. Child-caregiver reciprocal interaction is mediated through play, offering children a healthy emotional and cognitive development [14].

Regarding the relationships that are formed during play engagement, six stages have been identified [15]: (i) unoccupied play: children do not play but they occupy themselves watching anything that seems exciting to them. Otherwise, they play with their own body, follow their teacher, or just stand around; (ii) onlooker play: in this stage, children observe other children's play; (iii) solitary play: children play on their own even if they are in a room full of other children, without even noticing them; (iv) parallel play: children in this stage play next to each other without playing together, sharing toys or activities; (v) associative play: children play the same game, but they do not form connections with each other; and (vi) cooperative play: children that have reached the cooperative play stage are able to play with their friends while learning social skills.

Along with the changes in children's everyday life during the COVID-19 outbreak, it has been postulated that play has also changed. Concerns about the fewer opportunities for learning and play for children due to school closures, home confinement, social distancing, and lack of or limited access to outdoor activities have been reported [16,17]. Children's pretend play might also have changed, with COVID-19 invading their everyday play; for instance, children might pretend to be doctors and give medication due to COVID-19, as suggested in anecdotal evidence [18]. In many countries, governments have published guidelines regarding children's healthy play behaviors during the COVID-19 pandemic [19].

This review aims to examine how children's play has been affected during the COVID-19 pandemic, both quantitively and qualitatively, and how these changes have affected children's everyday life and wellbeing. Any differences related to gender, age, or other sociodemographic characteristics were explored.

\section{Methods}

\subsection{Selection of Studies}

Relevant studies were sought in the following databases up to 6 December 2020, concerning articles published in 2020 (time of the COVID-19 pandemic): PubMed, Google Scholar, EMBASE, SCOPUS, ERIC, PsycInfo, and JSTOR. Search terms included "outdoor play", "pretend play", "symbolic play", "imaginary play", "imaginative play", "play behavior", "video games", "outdoor activities", "sports", "childhood", "child", "children", "kid", "kids", "COVID-19", "SARS-CoV-19", "SARS-CoV-2", "2019-nCoV", and "novel coronavirus". In order to include as many related studies, references of eligible studies as well as of relevant articles were searched using a snowballing technique.

Articles that examined play behaviors and play in general in children during the COVID-19 outbreak were considered eligible. Considering play, indoor activities such as videogaming, playing board games, role playing, etc. and outdoor activities such as biking, free play, sports, etc. were eligible. As far as study design is concerned, case reports, cohort studies, cross-sectional studies, case series, and case-control studies were included. Studies evaluating reports from parents were also deemed eligible, in order to describe a comprehensive picture of children's behaviors. Studies written in English, Spanish, and French were chosen, and there was no gender restriction.

Two authors (A.K. and A.S.) working independently from one another in pairs performed the selection of studies. Data from eligible studies were extracted, including name of first author, region/country where the survey was conducted, language, study period, study design, sample size, age range, selection of sample, ascertainment and/or association with the COVID-19 epidemic, outcomes and methods/questionnaires used for measurements, statistical analysis, and main findings. 


\subsection{Quality Assessment}

The Newcastle Ottawa Scale for Cross-sectional Studies [20] and Newcastle Ottawa Scale for Cohort Studies [21] (Appendix A, Tables A1 and A2) were used to evaluate the risk of bias in eligible studies. The quality assessment was performed by two independent researchers (A.K. and A.S.).

\section{Results}

\subsection{Selection of Studies}

Seventeen studies on the topic were identified. Among them, six studies were conducted in America (four in Canada [22-25], one in the USA [26], and one in Mexico [27]) and 11 were performed in Europe (five in Spain [28-32], two in Portugal [33,34], two in Ireland [35,36], one in the UK [37], and one in Poland [38]). Four of them had overlapping samples, but they have been included in Table 1 in the "overlapping studies" section" as they offered additional information regarding the issue examined in this paper. The majority of studies were cross-sectional $(n=14)$, and only three were cohort studies (Table 1$)$. A total of 10,313 parents with one or more children $0-17$ years old, 2159 children $0-13$ years old who were represented by their parents (not specified if one or both parents participated in the research or how many children each parent had), 726 children and adolescents who reported for themselves, and 307 primary teachers reporting on children's play behaviors during the COVID-19 pandemic were gathered (Table 1. The data of cases where parents reported for their children and specific demographic data for their children were provided (e.g., sex percentage, mean age) are included in Table 1. 
Table 1. Descriptive characteristics of included studies.

\begin{tabular}{|c|c|c|c|c|c|c|c|c|c|c|}
\hline $\begin{array}{l}\text { First Author } \\
\text { (Year) }\end{array}$ & $\begin{array}{l}\text { Region, } \\
\text { Country }\end{array}$ & Language & Study Period & $\begin{array}{c}\text { Study } \\
\text { Design }\end{array}$ & Sample & $\begin{array}{c}\text { Sample } \\
\text { Size }\end{array}$ & Age Range & Selection of Sample & $\begin{array}{c}\text { Outcomes, } \\
\text { Way/Questionnaires } \\
\text { They Were Measured }\end{array}$ & Main Findings \\
\hline $\begin{array}{l}\text { Andrew et al. } \\
{[37](2020)}\end{array}$ & UK & English & $\begin{array}{l}29 \text { April to } 20 \\
\text { June } 2020\end{array}$ & $\begin{array}{c}\text { Cross- } \\
\text { sectional }\end{array}$ & $\begin{array}{l}\text { Parents with } \\
\text { at least one } \\
\text { child between } \\
\text { the ages of } 2 \\
\text { and } 15\end{array}$ & 5.582 & NR & $\begin{array}{l}\text { Nationally representative } \\
2019 \text { Labour Force Survey } \\
\text { (LFS) }\end{array}$ & Interview & $\begin{array}{l}\text { The rest of the children's days are filled with learning and } \\
\text { leisure activities, which include playing, reading, being } \\
\text { outdoors, socializing and on-screen time. Comparing } \\
\text { primary with secondary school children in the lockdown } \\
\text { period, we see that primary children are more likely to } \\
\text { spend time outdoors in a given hour and less likely to be } \\
\text { on-screen except for the early hours of the morning. }\end{array}$ \\
\hline $\begin{array}{l}\text { Arufe Giráldez; } \\
\text { Cachón Zagalaz } \\
\text { et al. [31] (2020) }\end{array}$ & Spain & Spanish & $\begin{array}{l}23 \text { March } \\
\text { 2020-6 May } \\
2020\end{array}$ & $\begin{array}{c}\text { Cross- } \\
\text { sectional }\end{array}$ & $\begin{array}{l}\text { Parents of } \\
\text { children in } \\
\text { Spain }\end{array}$ & $\begin{array}{l}837(50.2 \% \\
\text { males) }\end{array}$ & $\begin{array}{l}<12 \text { years old } \\
(\mathrm{M}=6.22) 0-2 \\
\text { years old: } 202, \\
\text { 3-6 years old: } \\
\text { 260, } 7-12 \\
\text { years old: } 375\end{array}$ & $\begin{array}{l}\text { Through social networks } \\
\text { and using as a filter } \\
\text { families with residence in } \\
\text { Spain and children under } \\
12 \text { years old }\end{array}$ & $\begin{array}{l}\text { Equipamiento y Uso de } \\
\text { Tecnologías de } \\
\text { Información y } \\
\text { Comunicación en los } \\
\text { Hogares (TIC-H2019) in } \\
\text { Spanish, self-registration } \\
\text { sheet ad hoc } \\
\text { questionnaire for parents }\end{array}$ & $\begin{array}{c}\text { Only } 13.1 \% \text { of children spend adequate time on everyday } \\
\text { physical activity. Children that spend less time playing } \\
\text { videogames, using a computer, watching television, and } \\
\text { using tablets or mobile phones spend more time on } \\
\text { physical activities. }\end{array}$ \\
\hline $\begin{array}{l}\text { Dunton et al. } \\
\text { [26] (2020) }\end{array}$ & $\begin{array}{l}\text { US, } 35 \\
\text { states } \\
\text { and the } \\
\text { District } \\
\text { of } \\
\text { Columbia. }\end{array}$ & English & $\begin{array}{l}25 \text { April to } 16 \\
\text { May } 2020 \text { and } \\
\text { a second } \\
\text { online survey } \\
\text { was } \\
\text { scheduled to } \\
\text { occur within } \\
6-12 \text { months }\end{array}$ & Cohort & Children & 211 & 5 to 13 years & $\begin{array}{l}\text { Respondents were } \\
\text { electronically invited } \\
\text { through various social } \\
\text { media platforms (e.g., } \\
\text { Facebook, Twitter) and } \\
\text { university-based } \\
\text { emailing lists of students, } \\
\text { faculty, and staff. }\end{array}$ & $\begin{array}{l}\text { Online self-report } \\
\text { questionnaire }\end{array}$ & $\begin{array}{l}90 \% \text { of children during the early-COVID-19 period chose } \\
\text { free play / unstructured activity (e.g., running around, tag) } \\
\text { and } 55 \% \text { went for a walk; } 10.4 \% \text { of children participated in } \\
\text { team sports training sessions or practice through remote } \\
\text { or streaming services, } 28.9 \% \text { participated in activity } \\
\text { classes or lessons (e.g., martial arts, dance, yoga) through } \\
\text { remote or streaming services, and } 2.4 \% \text { participated in } \\
\text { remote or streaming classes or sessions provided by a } \\
\text { health club or gym. Older children (age } 9-13 \text { ) vs. younger } \\
\text { children (ages 5-8) were more than five times as likely to } \\
\text { participate in team sports training session or practice } \\
\text { through remote or streaming services (OR }=5.40,95 \% \mathrm{CI}\end{array}$ \\
\hline $\begin{array}{c}\text { Egan et al. [36] } \\
\text { (2021) }\end{array}$ & Ireland & English & $\begin{array}{l}21 \text { May to } 3 \\
\text { June } 2020\end{array}$ & $\begin{array}{c}\text { Cross- } \\
\text { sectional }\end{array}$ & $\begin{array}{l}\text { Parents of } \\
\text { children 1-10 } \\
\text { years old }\end{array}$ & 512 & $1-10$ & $\begin{array}{l}\text { Cognition, Development, } \\
\text { and Learning Lab }\end{array}$ & Interview & $\begin{array}{l}90 \% \text { missed their friends, } 87 \% \text { missed playing with other } \\
\text { children, } 72 \% \text { said play was affected by restrictions, and } \\
34 \% \text { brought the virus into their play. Most children spent } \\
\text { more time playing outdoors, with games and toys and } \\
\text { on-screen activities, and } 80 \% \text { went for a walk in their } \\
\text { neighborhood at least } \\
\text { once a week, with over a third going for a walk every day. }\end{array}$ \\
\hline
\end{tabular}


Table 1. Cont.

\begin{tabular}{|c|c|c|c|c|c|c|c|c|c|c|}
\hline $\begin{array}{l}\text { First Author } \\
\text { (Year) }\end{array}$ & $\begin{array}{l}\text { Region, } \\
\text { Country }\end{array}$ & Language & Study Period & $\begin{array}{c}\text { Study } \\
\text { Design }\end{array}$ & Sample & $\begin{array}{l}\text { Sample } \\
\text { Size }\end{array}$ & Age Range & Selection of Sample & $\begin{array}{c}\text { Outcomes, } \\
\text { Way/Questionnaires } \\
\text { They Were Measured }\end{array}$ & Main Findings \\
\hline $\begin{array}{c}\text { Gambin et al. } \\
\text { [38] (2020) }\end{array}$ & Poland & English & 4-8 May 2020 & $\begin{array}{l}\text { Cross- } \\
\text { sectional }\end{array}$ & Parents & 459 & $18-73$ & $\begin{array}{l}\text { Online from the Polish } \\
\text { research panel } \\
\text { ARIADNA }\end{array}$ & $\begin{array}{l}\text { Brief version of the } \\
\text { Empathic Sensitivity } \\
\text { Questionnaire, The } \\
\text { Difficulties in Emotion } \\
\text { Regulation Scale Short } \\
\text { Form, Social Support } \\
\text { Scale, Parenting } \\
\text { Self-Agency Measure, as } \\
\text { well as The Scale of } \\
\text { Positive Experiences in } \\
\text { Parent-Child } \\
\text { Relationship during the } \\
\text { COVID-19 lockdown }\end{array}$ & $\begin{array}{l}\text { Parents and children may have some positive experiences } \\
\text { in their relationship during lockdown. Maybe, in some } \\
\text { families, experiencing distress or emotional arousal } \\
\text { caused parents to be more sensitive and focused on } \\
\text { children and relations with them to provide protection or } \\
\text { help, so despite struggling with a higher level of negative } \\
\text { emotions, they noticed new achievements from their } \\
\text { children, shared the joy of playing with them or felt the } \\
\text { satisfaction of creating new activities. }\end{array}$ \\
\hline $\begin{array}{l}\text { Giménez-Dasí } \\
\text { et al. [28] (2020) }\end{array}$ & $\begin{array}{l}\text { Madrid, } \\
\text { Spain }\end{array}$ & English & $\begin{array}{l}\text { March 2020, } \\
\text { and 8-25 } \\
\text { April } 2020\end{array}$ & cohort & $\begin{array}{l}\text { Families with } \\
\text { children aged } \\
\text { between } 3.2 \\
\text { and } 11.1 \text { years }\end{array}$ & 167 & NR & $\begin{array}{l}\text { Children recruited from } \\
\text { two public school in } \\
\text { Madrid. }\end{array}$ & $\begin{array}{l}\text { System of Evaluation of } \\
\text { Children and } \\
\text { Adolescents (SENA) and } \\
\text { online }\end{array}$ & $\begin{array}{l}\text { Positive changes in some families, referring to } \\
\text { improvements in mood and to the positive effect of the } \\
\text { greater availability of free time and family time. }\end{array}$ \\
\hline $\begin{array}{l}\text { Martinez et al. } \\
\text { [29] (2020) }\end{array}$ & Spain & Spanish & $\begin{array}{l}21 \text { March } \\
2020-5 \text { April } \\
2020\end{array}$ & $\begin{array}{c}\text { Cross- } \\
\text { sectional }\end{array}$ & $\begin{array}{l}\text { Parents of } \\
\text { children and } \\
\text { adolescents in } \\
\text { Spain }\end{array}$ & $\begin{array}{l}435(44.0 \% \\
\text { males, } 3.8 \% \\
\text { not stated })\end{array}$ & $\begin{array}{l}8-17 \text { years } \\
\text { old }(8-12 \\
13-17)\end{array}$ & $\begin{array}{l}\text { Via social networks and } \\
\text { survey on LimeSurvey } \\
\text { platform }\end{array}$ & $\begin{array}{l}\text { 25-question questionnaire } \\
\text { for children (both open } \\
\text { and close questions) }\end{array}$ & $\begin{array}{l}9.30 \% \text { of male participants and } 3.70 \% \text { of female } \\
\text { participants }(4.30 \% \text { - } 12 \text { years old, and } 10.70 \% 13-17 \text { years } \\
\text { old) did not practice any sport or carry out any physical } \\
\text { activity during the confinement measures. } 21.50 \% \text { of male } \\
\text { participants and } 13.40 \% \text { of female participants }(14.10 \% \\
8-12 \text { years old, and } 14.10 \% 13-17 \text { years old) did not } \\
\text { practice any hobby during the confinement measures. } \\
\text { Furthermore, playing (both online gaming and } \\
\text { conventional games) was the second most important } \\
\text { factor (after family) for children and adolescents' } \\
\text { happiness }(22.77 \% \text { boys }<12 \text { years old, } 26.09 \% \text { girls }<12 \\
\text { years old, } 16.65 \text { male adolescents }(13-17), 25.86 \% \text { female } \\
\text { adolescents }(13-17)) \text {. } 23.77 \% \text { of the participants liked the } \\
\text { fact that they had more free time to play at home. }\end{array}$ \\
\hline
\end{tabular}


Table 1. Cont.

\begin{tabular}{|c|c|c|c|c|c|c|c|c|c|c|}
\hline $\begin{array}{l}\text { First Author } \\
\text { (Year) }\end{array}$ & $\begin{array}{l}\text { Region, } \\
\text { Country }\end{array}$ & Language & Study Period & $\begin{array}{l}\text { Study } \\
\text { Design }\end{array}$ & Sample & $\begin{array}{l}\text { Sample } \\
\text { Size }\end{array}$ & Age Range & Selection of Sample & $\begin{array}{c}\text { Outcomes, } \\
\text { Way/Questionnaires } \\
\text { They Were Measured }\end{array}$ & Main Findings \\
\hline $\begin{array}{l}\text { Medrano et al. } \\
\text { [30] (2020) }\end{array}$ & $\begin{array}{l}\text { Navarra } \\
\text { (Spain) }\end{array}$ & English & $\begin{array}{l}\text { September- } \\
\text { December } \\
2019 \text { and } \\
\text { March-April } \\
2020\end{array}$ & Cohort & $\begin{array}{l}\text { Children and } \\
\text { adolescents in } \\
\text { Spain }\end{array}$ & $\begin{array}{c}291 \\
\text { children } \\
(12.1 \pm 2.4 \\
\text { years at } \\
\text { baseline, } \\
47.8 \% \text { girls) } \\
\text { included in } \\
\text { the MUGI } \\
\text { project and } \\
113 \\
\text { children } \\
\text { from the } \\
\text { whole } \\
\text { sample } \\
\text { agreed to } \\
\text { participate } \\
\text { in the } \\
\text { second } \\
\text { evaluation } \\
\text { and } \\
\text { completed } \\
\text { the online } \\
\text { question- } \\
\text { naire }(39 \% \\
\text { participa- } \\
\text { tion rate; } \\
12.0 \pm 2.6 \\
\text { years at } \\
\text { baseline, } \\
48.7 \% \\
\text { girls). }\end{array}$ & 8 to 16 years & MUGI project & $\begin{array}{l}\text { Demographic values, The } \\
\text { Youth Activity Profile" } \\
\text { questionnaire (YAP), } \\
\text { Mediterranean Diet } \\
\text { Quality Index for } \\
\text { children and teenagers } \\
\text { (KIDMED) questionnaire, } \\
\text { lifestyle questionnaires } \\
\text { during confinement. }\end{array}$ & $\begin{array}{l}\text { During the COVID-19 confinement, physical activity } \\
(-91 \pm 55 \mathrm{~min} / \mathrm{d}, p<0.001) \text { and screen time }( \pm 2.6 \mathrm{~h} / \mathrm{d} \text {, } \\
p<0.001) \text { worsened, whereas the KIDMED score } \\
\text { improved }(0.5 \pm 2.2 \text { points, } p<0.02) \text {. The decrease in PA } \\
\text { was higher in children with a mother of non-spanish } \\
\text { origin }(-1.8 \pm 0.2 \mathrm{vs}-1.5 \pm 0.1 \mathrm{~h} / \mathrm{d}, p<0.04 \text { ) or with } \\
\text { non-university studies }(-1.7 \pm 0.1 \mathrm{vs} \text {. }-1.3 \pm 0.1 \mathrm{~h} / \mathrm{d} \\
p<0.005) \text { in comparison to their counterparts. }\end{array}$ \\
\hline $\begin{array}{l}\text { Moore et al. [24] } \\
\quad(2020)\end{array}$ & Canada & English & $\begin{array}{l}1 \text { month after } \\
\text { the WHO } \\
\text { declared } \\
\text { COVID-19 a } \\
\text { global } \\
\text { pandemic }\end{array}$ & $\begin{array}{c}\text { Cross- } \\
\text { sectional }\end{array}$ & $\begin{array}{l}\text { Parents of } \\
\text { children and } \\
\text { adolescents } \\
\text { 5-17 years } \\
\text { old }\end{array}$ & $\begin{array}{l}1474 \\
\text { children } \\
\text { and } \\
\text { adolescents } \\
(46 \% \\
\text { males })\end{array}$ & $\begin{array}{l}5-17(5-11 \\
\text { and 11-17) }\end{array}$ & $\begin{array}{c}\text { Survey via } \\
\text { Maru/Matchbox }\end{array}$ & $\begin{array}{l}\text { Canadian 24-Hour } \\
\text { Movement Guidelines for } \\
\text { Children and Youth }\end{array}$ & $\begin{array}{c}1-5 \text { scale ( } 3 \text { no change): Walks or bikes in neighborhood: } \\
\text { children overall } 2.57 \text {, boys } 2.54 \text {, girls } 2.61 \text {. } \\
\text { Physical activity or sports outside: children overall } 2.28 \text {, } \\
\text { boys } 2.26 \text {, girls } 2.30 \text {. } \\
\text { Physical activity or sports inside: children overall } 2.94 \text {, } \\
\text { boys } 3.01 \text {, girls } 2.88 \\
\text { Outdoor play: children overall } 2.58 \text {, boys } 2.57 \text {, girls } 2.59 \text {. } \\
\text { Indoor Play: children overall } 3.85 \text {, boys } 3.86 \text {, girls } 3.84 \text {. }\end{array}$ \\
\hline
\end{tabular}


Table 1. Cont.

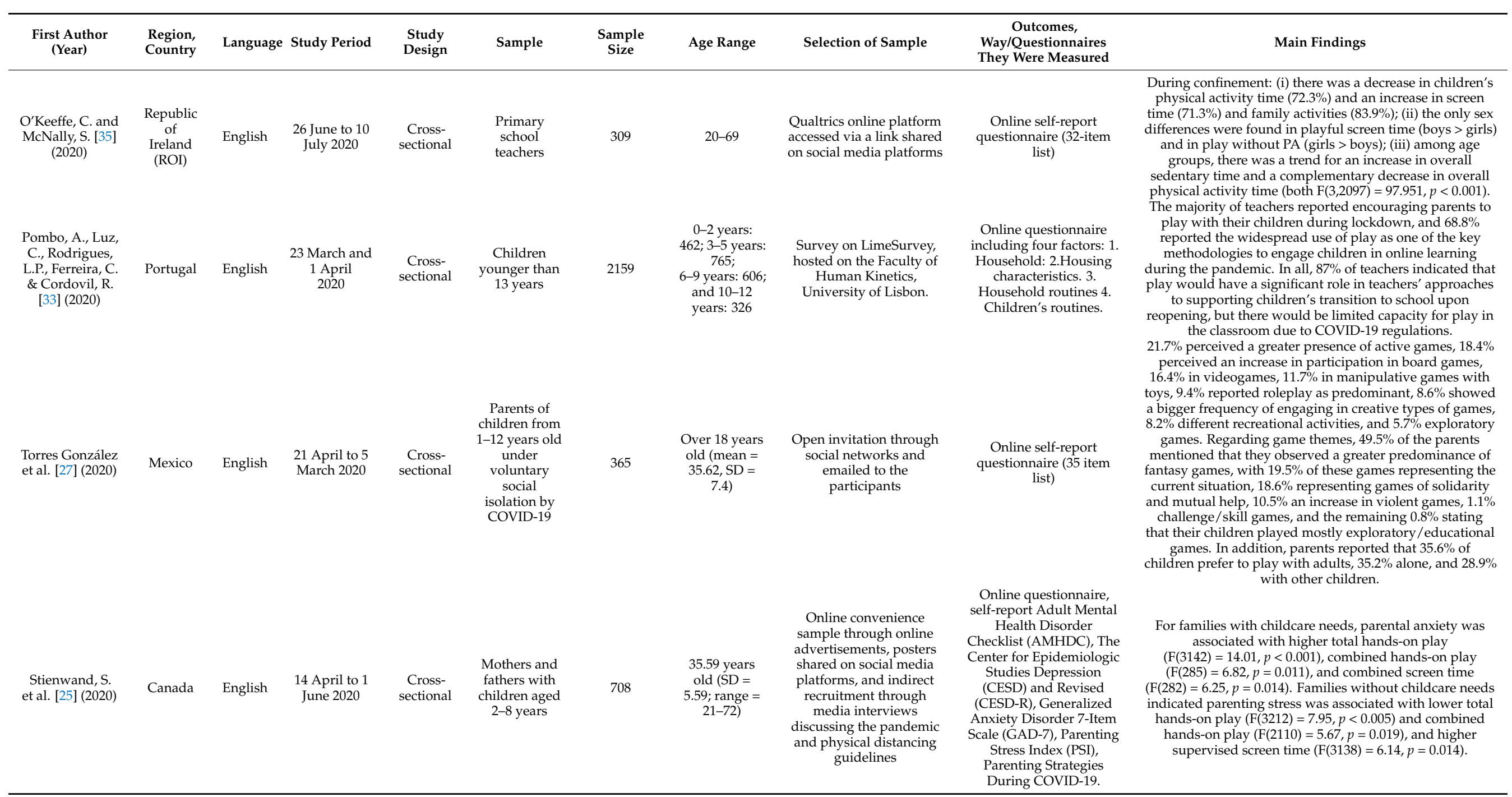


Table 1. Cont.

\begin{tabular}{|c|c|c|c|c|c|c|c|c|c|c|}
\hline $\begin{array}{l}\text { First Author } \\
\text { (Year) }\end{array}$ & $\begin{array}{l}\text { Region, } \\
\text { Country }\end{array}$ & Language & Study Period & $\begin{array}{l}\text { Study } \\
\text { Design }\end{array}$ & Sample & $\begin{array}{l}\text { Sample } \\
\text { Size }\end{array}$ & Age Range & Selection of Sample & $\begin{array}{c}\text { Outcomes, } \\
\text { Way/Questionnaires } \\
\text { They Were Measured }\end{array}$ & Main Findings \\
\hline $\begin{array}{c}\text { Arufe Giráldez, } \\
\text { Sanmiguel- } \\
\text { Rodríguez et al. } \\
\text { [32] (2020) } \\
\text { (overlapping } \\
\text { with Arufe } \\
\text { Giráldez, } \\
\text { Cachón Zagalaz } \\
\text { et al. [31] 2020) }\end{array}$ & Spain & English & $\begin{array}{l}23 \text { March } \\
\text { 2020-6 May } \\
2020\end{array}$ & $\begin{array}{c}\text { Cross- } \\
\text { sectional }\end{array}$ & $\begin{array}{l}\text { Parents of } \\
\text { children in } \\
\text { Spain }\end{array}$ & $\begin{array}{l}280(51.1 \% \\
\text { males) }\end{array}$ & $\begin{array}{c}\text { dies with overla } \\
0-4 \text { years old } \\
\text { (M = 2.44), } \\
<0 \text { years old: } \\
9.3 \%(n=26) ; \\
1-2 \text { years old: } \\
40.4 \% \\
(n=113) ; 3-4 \\
\text { years old: } \\
50.4 \% \\
(n=140)\end{array}$ & $\begin{array}{l}\text { Through social networks } \\
\text { and using as a filter } \\
\text { families with residence in } \\
\text { Spain and children under } \\
5 \text { years old }\end{array}$ & $\begin{array}{l}\text { Equipamiento y Uso de } \\
\text { Tecnologías de } \\
\text { Información y } \\
\text { Comunicación en los } \\
\text { Hogares (TIC-H2019) in } \\
\text { Spanish, self-reported } \\
\text { questionnaire for parents }\end{array}$ & $\begin{array}{l}\text { Overall decrease in outdoor play. Differences in outdoor } \\
\text { play across different Canadian provinces. }\end{array}$ \\
\hline $\begin{array}{l}\text { De Lannoy et al. } \\
\text { [22] (2020) } \\
\text { (overlapping } \\
\text { with Moore } \\
\text { et al., [24] } 2020 \\
\text { and Mitra et al., } \\
\text { [23] } 2020\end{array}$ & Canada & English & $\begin{array}{l}1 \text { month after } \\
\text { the WHO } \\
\text { declared } \\
\text { COVID-19 a } \\
\text { global } \\
\text { pandemic }\end{array}$ & $\begin{array}{c}\text { Cross- } \\
\text { sectional }\end{array}$ & $\begin{array}{c}\text { Parents of } \\
\text { children and } \\
\text { adolescents } \\
5-17 \text { years } \\
\text { old }\end{array}$ & $\begin{array}{l}1472 \\
\text { children } \\
\text { and } \\
\text { adolescents } \\
(46 \% \\
\text { males) }\end{array}$ & $\begin{array}{l}5-17(5-11 \\
\text { and } 11-17)\end{array}$ & $\begin{array}{l}\text { Survey via } \\
\text { Maru/Matchbox }\end{array}$ & $\begin{array}{l}\text { Canadian 24-H } \\
\text { Movement Guidelines for } \\
\text { Children and Youth }\end{array}$ & 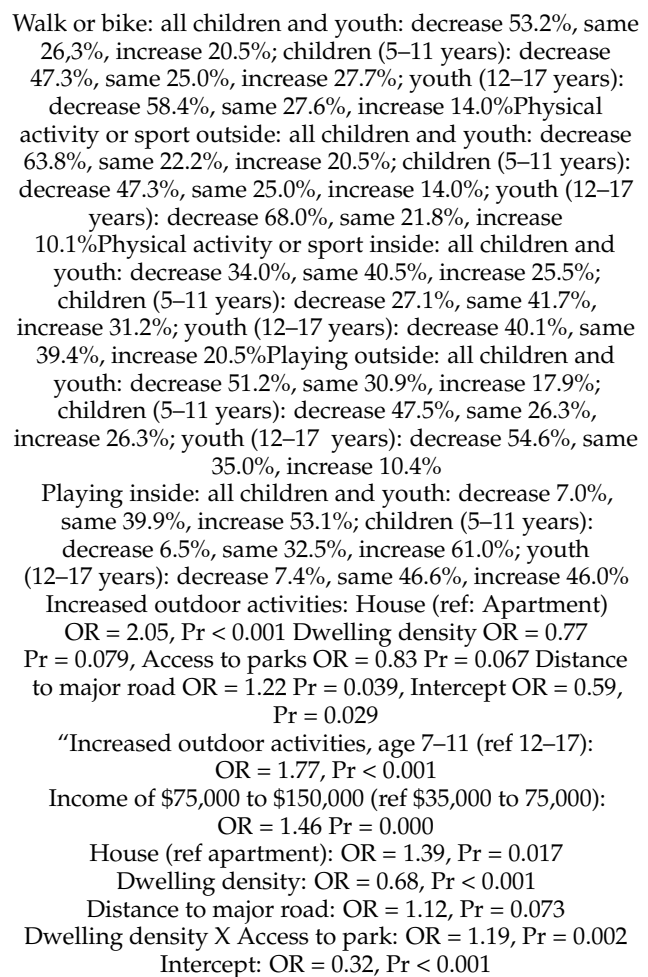 \\
\hline
\end{tabular}


Table 1. Cont.

\begin{tabular}{|c|c|c|c|c|c|c|c|c|c|c|}
\hline $\begin{array}{l}\text { First Author } \\
\text { (Year) }\end{array}$ & $\begin{array}{l}\text { Region, } \\
\text { Country }\end{array}$ & Language & Study Period & $\begin{array}{l}\text { Study } \\
\text { Design }\end{array}$ & Sample & $\begin{array}{l}\text { Sample } \\
\text { Size }\end{array}$ & Age Range & Selection of Sample & $\begin{array}{c}\text { Outcomes, } \\
\text { Way/Questionnaires } \\
\text { They Were Measured }\end{array}$ & Main Findings \\
\hline $\begin{array}{c}\text { Mitra et al. [23] } \\
\text { (2020) } \\
\text { (overlapping } \\
\text { with Moore } \\
\text { et al., [24] 2020 } \\
\text { and De Lannoy } \\
\text { et al., [22] 2020) }\end{array}$ & Canada & English & $\begin{array}{l}1 \text { month after } \\
\text { the WHO } \\
\text { declared } \\
\text { COVID-19 a } \\
\text { global } \\
\text { pandemic }\end{array}$ & $\begin{array}{c}\text { Cross- } \\
\text { sectional }\end{array}$ & $\begin{array}{l}\text { Parents of } \\
\text { children and } \\
\text { adolescents } \\
5-17 \text { years } \\
\text { old }\end{array}$ & $\begin{array}{l}1473-690 \\
\text { children- } \\
(46 \% \\
\text { males })\end{array}$ & $\begin{array}{l}5-17(5-11 \\
\text { and } 11-17)\end{array}$ & $\begin{array}{c}\text { Survey via } \\
\text { Maru/Matchbox }\end{array}$ & $\begin{array}{l}\text { Parents' self-report in 11 } \\
\text { movement behaviors: 1) } \\
\text { walking or cycling, 2) } \\
\text { physical activity or sport } \\
\text { outside, } \\
\text { 3) physical activity or } \\
\text { sport inside, 4) household } \\
\text { chores, 5) playing } \\
\text { outside, 6) playing inside, } \\
\text { 7) screen time, 8) social } \\
\text { media use, 9) } \\
\text { othernon-screen-based } \\
\text { sedentary activities, 10) } \\
\text { sleep } \\
\text { duration, and 11) sleep } \\
\text { quality. }\end{array}$ & $\begin{array}{c}\text { Daily physical activity in minutes: } \leq 1 \text { year } 6.54 \mathrm{~min} \text {; } \\
1-2 \text { years } 35.58 \text { min; } 3-4 \text { years } 33.45 \mathrm{~min} \text {. } \\
\text { Creativity level (10-point scale): } \leq 1 \text { year } 5.65 ; 1-2 \text { years } \\
7.70 ; 3-4 \text { years } 8.09\end{array}$ \\
\hline $\begin{array}{c}\text { Pombo, A., A., } \\
\text { Luz, C., } \\
\text { Rodrigues, L.P. } \\
\text { \& Cordovil, R. } \\
\text { [34] (2021) } \\
\text { (overlapping } \\
\text { with Pombo, A., } \\
\text { Luz, C., } \\
\text { Rodrigues, L.P., } \\
\text { Ferreira, C., and } \\
\text { Cordovil, R. [33] } \\
\text { 2020) }\end{array}$ & Portugal & English & $\begin{array}{l}23 \text { March and } \\
1 \text { April } 2020\end{array}$ & $\begin{array}{c}\text { Cross- } \\
\text { sectional }\end{array}$ & $\begin{array}{l}\text { Children } \\
\text { younger than } \\
13 \text { years }\end{array}$ & 2159 & $\begin{array}{l}0-2 \text { years: } \\
462 ; 3-5 \text { years: } \\
765 ; \\
6-9 \text { years: } 606 ; \\
\text { and } 10-12 \\
\text { years: } 326\end{array}$ & $\begin{array}{l}\text { Survey on LimeSurvey, } \\
\text { hosted on the Faculty of } \\
\text { Human Kinetics, } \\
\text { University of Lisbon. }\end{array}$ & $\begin{array}{l}\text { Questionnaire including } \\
\text { demographic values, } \\
\text { household characteristics, } \\
\text { children's routines, and } \\
\text { five categories: a) } \\
\text { intellectual activity } \\
\text { (school assignments and } \\
\text { online classes), b) playful } \\
\text { screen time (games, } \\
\text { movies, social networks, } \\
\text { Internet, audio and video } \\
\text { calls), c) play without PA } \\
\text { (reading, drawing, } \\
\text { painting, board games, } \\
\text { cards, Legos, and so on), } \\
\text { d) play with physical } \\
\text { activity (hide and seek, } \\
\text { jumping, tag, and so on), } \\
\text { e) PA (organized PA } \\
\text { indoors, PA outdoors, } \\
\text { walking the dog). }\end{array}$ & $\begin{array}{l}\text { Boys and girls did not differ in the \%PA in any of the age } \\
\text { groups; children with an outdoor space and who had } \\
\text { other children in the household were significantly more } \\
\text { active ( } p<0.001) \text {; children from families with all adults } \\
\text { working from home showed lower levels of \%PA; and } \\
\text { being younger, having a big outdoor space, having other } \\
\text { children in the household, and having at least one adult } \\
\text { not working from home were significant positive } \\
\text { predictors of children's \%PA, explaining } 21 \% \text { of the overall } \\
\text { variance. }\end{array}$ \\
\hline
\end{tabular}




\subsection{Outdoor and Indoor Play}

Children's outdoor play was affected during the COVID-19 pandemic restrictions, with outdoor activities being restricted in regions with more severe measures compared to areas with looser confinement measures [22,30,34]. More specifically, a Canadian study revealed that children and adolescents (5-11 years) only reduced their time spent walking or biking by $47.3 \%$, whereas only $27.7 \%$ increase it [23]. In addition, $63.8 \%$ of Canadian children participating in the aforementioned study decreased their outdoor physical activity or their engagement with outdoor sports and $47.5 \%$ reduced their time in outdoor playing. By contrast, an increase of $31.2 \%$ in indoor physical activity or engagement with indoor sports, and an increase of $61.0 \%$ in time spent playing inside were noted [23]. On the other hand, $80 \%$ of children in an Irish study went for a walk near their neighborhood at least once a week, while $1 / 3$ walked on a daily basis [36].

Primary school children were more likely to spend time outdoors instead of using screens as leisure time (expect during the morning hours due to mandatory attendance of online classes) than their secondary school counterparts [37]. During lockdown, the majority of children aged 5-8 years $(97.4 \%)$ and $9-13$ years $(80.6 \%)$ preferred free play and/or unstructured physical activity (e.g., running around or other active games) [26].

Decline in time spent on both outdoor and indoor physical activity (walking and biking) and both indoor and outdoor play in children were inversely associated with parental age [24]. Thus, children of older parents spent less time playing. This decline was also positively associated with parents' encouragement toward physical activity [24], with parents' support and participation, with household type (detached or not) - with the exception of indoor play [24,33] —and with there being at least one adult free from work [33]. Physical activity was also positively associated with the existence of more than one child in the house and negatively associated with parents working from home [33].

A study on Spanish children revealed that $40.1 \%$ practiced some kind of physical activity at home, including dancing and sports, almost every day, $22.2 \%$ various times a day, whereas $37 \%$ of them never practiced any kind of physical activity or did so only a few times per week [29]. On the other hand, reading books and stories was a more unpopular option for children ( $25.6 \%$ did not read any books, $32.6 \%$ read only a few times, and $29.7 \%$ read books almost every day, while only $12.1 \%$ did so multiple times a day), although sufficient access to books and board games at home was reported [29].

During the lockdown measures, children's free play (under 12 years old) was negatively associated with the number of television and videogame devices at home and with time spent on smartphones, tablets, or videogame devices per day [31]. Children in Spain watched television for $80.38 \mathrm{~min}$ per day, played videogames for $18.78 \mathrm{~min}$ per day, used smart phones for $14.58 \mathrm{~min}$ per day and tablets $28.47 \mathrm{~min}$ per day [31]. Furthermore, children under 5 years old watched television for $65.33 \mathrm{~min}$ per day, used tablets for $17.10 \mathrm{~min}$ per day and mobile phones for 8.34 min per day [32]. Both mothers and fathers in the UK spent twice as much time on active childcare during the COVID-19 pandemic (including playing games) versus 2014-2015 (35), while indoor play was positively associated with parental discouragement of children using screens [24].

\subsection{The Types of Play}

During lockdown, a Mexican study examined the changes in children's play behaviors during the COVID-19 pandemic [27]; according to their parents' observations, $21.7 \%$ of children were more engaged with active games, $18.4 \%$ with board games, $16.4 \%$ with videogames, and $11.7 \%$ preferred manipulative games with toys (games using objects to explore a concrete idea), while an increase in violent games compared to before COVID-19 was noted (10.5\%). Moreover, $9.4 \%$ of parents reported that their children liked role playing, $8.6 \%$ played creative types of games, $8.2 \%$ engaged in various recreational activities, and $5.7 \%$ in exploratory games. The majority of these were fantasy games (49.5\%), while $1.1 \%$ were skills games and $8 \%$ educational games, with $19.5 \%$ of them representing the current situation (i.e., pandemic-focused games) and $18.5 \%$ of them being games 
focusing on helping others or showing solidarity in general. More than one third of children $(35.6 \%)$ preferred to play with adults and $35.2 \%$ alone, while only $28.9 \%$ preferred to play with other children [27].

The emotional state of children was affected by the lack of social play during COVID-19 lockdown; the majority missed their friends $(90 \%)$ or playing with other children in general $(87 \%)$, while approximately one third of them (34\%) included COVID-19 as part of their play [36]. Playing with family members was associated with stronger bonds within the family and improvement in children's mood [38]. In fact, according to Martinez et al. [29], playing (both videogaming and conventional play) was the second most important factor that contributed to children's happiness (right after family). Furthermore, screen time included not only videogames or social media roaming [30,34], but also different types of physical activity (e.g., team sports, yoga, martial arts, gym sessions), offered through streaming services (in countries such as the USA, where this feature was offered), with older children (9-13) engaging five times more frequently in remote team sports activities than their younger counterparts (OR $=5.40,95 \%$ CI 1.70-17.15) [26].

Parents were also concerned about their children's play behaviors. More specifically, parents who needed childcare for their children experienced anxiety regarding hands-on play and screen time [25], while a Spanish study showed that having parents of foreign origin was negatively associated with physical activity time [30].

Teachers' role in enhancing play among children was important as well [35]. The majority of teachers encouraged parents to engage in playful activities during lockdown. During online learning, $68.8 \%$ of them used educational games and other activities, while $87 \%$ were eager to use play as a mediator in face-to-face learning after returning to the classroom.

\subsection{Risk of Bias}

Of 14 cross-sectional studies, 1 scored 0/10, 2 scored 4/10, 1 scored 5/10, 3 scored $6 / 10,6$ scored $7 / 10$, and 1 scored $8 / 10$ in the Newcastle-Ottawa Scale. In most studies $(n=10)$, the tool for accessing children's play was not validated (Table A1). Regarding cohort studies, all three of them were of good quality; however, the non-responder rate was not justified (Table A2).

\section{Discussion}

The COVID-19 pandemic created a new reality, affecting all members of the global community, including children, as one of the most vulnerable groups. Those changes were reflected not only upon access to education and physical and psychological safety, but also upon social and physical activities $[39,40]$. This review addressed an important factor in children's life during the ongoing COVID-19 pandemic, namely, children's play behaviors, providing valuable data regarding both children's indoor and outdoor activities. Various data from different regions of Europe and North America were retrieved, including 17 articles [22-38].

According to this review, a decrease in play behaviors was noted in outdoor activities, due to confinement measures across countries $[22,29,30,33]$. Similar findings were provided by Graber et al. describing that children's access to play was limited during periods of quarantine (e.g., hospitalization, refugee camp), but not providing a significant change in children's play behaviors overall [41]. Indeed, most studies concluded that children decreased the time spent on physical activity and mostly on outdoor activities. In most countries, restrictive measures prohibited or at least discouraged parents from using playgrounds or outdoor sports; thus, outdoor activities were limited among both boys and girls [23]. Those findings represent a challenge in light of the guidelines of the World Health Organization, which defines that children and adolescents aged 5-17 years old should exercise, in moderate to high intensity, at least $60 \mathrm{~min}$ daily, mainly through aerobic exercises [42]. Overall, outdoor play connects children with nature and make them more active and curious, while also boosting their immune system and regulating their sleep routines $[43,44]$. 
During lockdown, children spent their time on various indoor activities. According to this review, children often chose videogames using a television, PC, tablet, or smartphone, while reading books and playing board games were not so popular [29,31]. Studies during the ongoing COVID-19 pandemic noted that there was an increase in screen time among children, not only for educational purposes, but also for leisure activities [45]. The American Pediatric Association proposed that children's time in front of screens should be determined by their age, providing parents with a useful guide [46].

Although there were limitations in activities, both indoor and outdoor, children never gave up their imagination. They chose different types of play activities, including their siblings or parents in them whenever they were available, leading to stronger bonds and improving their mood $[27,28,34,38]$. Additionally, the importance of play among children emerged as a stress coping mechanism [40]. In general, children engaging in play and related activities also present with better social skills, enhanced cognitive function, reduced anxiety, and fewer depressive symptoms $[47,48]$. It is, however, important to underline the fact that social play has been limited during the pandemic, and children shared that they missed their friends [36]. Since the COVID-19 outbreak and the measures taken by each country is an unprecedented situation, we do not know yet the impact that it may have on children's and adolescents' peer bonding, or whether children and adolescents have discovered other means and coping mechanisms (e.g., video calls with their friends).

Commenting on the external validity of this review, all studies were conducted in countries with high-income economies - with the exception of the study by Torres Gonzalez et al. [27], which was conducted in an upper-middle-income country (Mexico); studies were performed in Europe and America; there were no eligible studies from countries with a different socioeconomic background and culture (e.g., from African or Asian countries). Moreover, a lack of investigation around associations with the sociocultural background of the families was noted.

Play activities are an integral part of children's everyday life, incorporating physical, mental, and psychosocial benefits. The importance of maintaining a play routine is essential, but the new reality imposed by the ongoing COVID-19 pandemic has disrupted it. Parents, in cooperation with teachers and health providers, should reinforce children's opportunities to engage in both outdoor and indoor activities, during and after the ongoing COVID-19 pandemic.

Author Contributions: Conceptualization, M.T., T.N.S. and A.T.; methodology, A.K., A.S., E.P. and T.N.S.; investigation, A.K., A.S. and E.P.; writing-original draft preparation, A.K., A.S., E.P. and T.P.; writing-review and editing T.P., T.N.S. and A.T.; visualization, M.T., T.P. and E.P.; supervision, M.T., A.T. and T.N.S. All authors have read and agreed to the published version of the manuscript.

Funding: This research received no external funding.

Institutional Review Board Statement: Not applicable.

Informed Consent Statement: Not applicable.

Data Availability Statement: Data are included within the article.

Conflicts of Interest: The authors declare no conflict of interest. 


\section{Appendix A}

Table A1. Newcastle-Ottawa for Cross-sectional studies.

\begin{tabular}{|c|c|c|c|c|c|c|c|c|}
\hline & & & Selection & & Comparability & & me & Total \\
\hline First author (year) & $\begin{array}{l}\text { Representativeness of the } \\
\text { sample }\end{array}$ & Sample size & Non-respondents & Ascertainment of exposure & $\begin{array}{l}\text { The subjects in different } \\
\text { outcome groups are } \\
\text { comparable based on the study } \\
\text { design or analysis. } \\
\text { Confounding factors are } \\
\text { controlled. }\end{array}$ & $\begin{array}{l}\text { Assessment of } \\
\text { outcome }\end{array}$ & Statistical test & \\
\hline \multirow{2}{*}{ Andrew et al. [37] (2020) } & * & * & - & * & $* *$ & * & - & $6 / 10$ \\
\hline & $\begin{array}{l}\text { parents recruited via } \\
\text { online survey company }\end{array}$ & 5582 & No description & $\begin{array}{c}\text { Non-validated but tool is } \\
\text { described }\end{array}$ & $\begin{array}{c}\text { Family structure, employment, } \\
\text { gender }\end{array}$ & Self-report & no & \\
\hline \multirow[t]{2}{*}{$\begin{array}{l}\text { Arufe Giráldez, Cachón } \\
\text { Zagalaz et al. [31] (2020) }\end{array}$} & - & - & - & $* *$ & $* *$ & * & * & $6 / 10$ \\
\hline & $\begin{array}{l}\text { Non-experimental } \\
\text { design for the } \\
\text { recruitment of the } \\
\text { participants }\end{array}$ & 837 & No description & Validated measurement tool & $\begin{array}{l}\text { Age, number of televisions, } \\
\text { PCs and/or tablets at home }\end{array}$ & Self-report & yes & \\
\hline Egan et al. [36] (2021) & No description & $\begin{array}{c}- \\
\text { No description }\end{array}$ & $\begin{array}{c}- \\
\text { No description }\end{array}$ & $\stackrel{-}{-}$ & $\stackrel{-}{-}$ No description & $\stackrel{-}{-}$ No description & $\begin{array}{c}- \\
\text { no }\end{array}$ & $0 / 10$ \\
\hline \multirow[t]{2}{*}{$\begin{array}{l}\text { Gambin, M. et al. [38] } \\
\text { (2020) }\end{array}$} & * & - & * & * & $* *$ & * & * & $7 / 10$ \\
\hline & $\begin{array}{l}\text { Parents recruited via } \\
\text { online platform }\end{array}$ & 459 & $\begin{array}{c}\text { From } 514,459 \text { were } \\
\text { eligible }\end{array}$ & $\begin{array}{c}\text { Non-validated but tool is } \\
\text { described }\end{array}$ & $\begin{array}{l}\text { Gender, residence, education, } \\
\text { marital status }\end{array}$ & Self-report & yes & \\
\hline \multirow[t]{2}{*}{ Moore et al. [24] (2020) } & $*$ & - & * & $*$ & $* *$ & * & * & $7 / 10$ \\
\hline & Parents & 1472 & $31 / 1503$ & $\begin{array}{c}\text { Non-validated but tool is } \\
\text { described }\end{array}$ & Gender and age of the child & Self-report & yes & \\
\hline \multirow{2}{*}{$\begin{array}{c}\text { O'Keeffe, C. and } \\
\text { McNally, S. [35] (2020) }\end{array}$} & * & - & * & * & $* *$ & * & * & $7 / 10$ \\
\hline & Snowball sampling & 309 & $\begin{array}{c}\text { From } 351,309 \text { were } \\
\text { eligible }\end{array}$ & $\begin{array}{l}\text { Non-validated but tool is } \\
\text { described }\end{array}$ & $\begin{array}{l}\text { Gender, age, professional } \\
\text { characteristics }\end{array}$ & Self-report & yes & \\
\hline $\begin{array}{c}\text { Pombo, A., Luz, C., } \\
\text { Rodrigues, L.P., Ferreira, } \\
\text { C., and Cordovil, R. [33] } \\
\text { (2020) }\end{array}$ & * & * & - & * & $* *$ & * & * & $7 / 10$ \\
\hline
\end{tabular}


Table A1. Cont.

\begin{tabular}{|c|c|c|c|c|c|c|c|c|}
\hline & & & ection & & Comparability & & & Total \\
\hline \multirow{3}{*}{$\begin{array}{l}\text { Stienwandt, S. et al. [25] } \\
(2020)\end{array}$} & $\begin{array}{l}\text { Parents recruited via } \\
\text { online survey }\end{array}$ & 2159 & No description & $\begin{array}{c}\text { Non-validated but tool is } \\
\text { described }\end{array}$ & Age, gender & Self-report & yes & \\
\hline & * & * & - & $* *$ & $* *$ & * & * & $8 / 10$ \\
\hline & $\begin{array}{l}\text { Parents recruited } \\
\text { through online } \\
\text { advertisements, posters } \\
\text { on social media } \\
\text { platforms, and indirect } \\
\text { recruitment through } \\
\text { media interviews } \\
\text { discussing the pandemic } \\
\text { and physical distancing } \\
\text { guidelines }\end{array}$ & 708 & No description & $\begin{array}{c}\text { Online questionnaire, } \\
\text { self-report Adult Mental } \\
\text { Health Disorder Checklist } \\
\text { (AMHDC), The Center for } \\
\text { Epidemiologic Studies } \\
\text { Depression (CESD) and } \\
\text { Revised (CESD-R), } \\
\text { Generalized Anxiety } \\
\text { Disorder 7-Item Scale } \\
\text { (GAD-7), Parenting Stress } \\
\text { Index (PSI), Parenting } \\
\text { Strategies during COVID-19 }\end{array}$ & $\begin{array}{l}\text { Maternal and paternal } \\
\text { education level, household } \\
\text { employment status during } \\
\text { COVID-19, total annual } \\
\text { household income, marital } \\
\text { status, number of children }\end{array}$ & Self-report & yes & \\
\hline \multirow[t]{3}{*}{$\begin{array}{c}\text { Torres González et al. } \\
\text { [27] (2020) }\end{array}$} & * & - & - & $*$ & ** & * & * & $6 / 10$ \\
\hline & $\begin{array}{c}\text { Online recruitment: } \\
\text { parents of children from } \\
1 \text { to } 12 \text { years old under } \\
\text { voluntarysocial isolation } \\
\text { by COVID-19 }\end{array}$ & 365 & No description & $\begin{array}{c}\text { Non-validated but tool is } \\
\text { described }\end{array}$ & $\begin{array}{l}\text { Gender, marital status, } \\
\text { socioeconomic status }\end{array}$ & Self-report & yes & \\
\hline & & & Rese & with Overlapping Sample & & & & \\
\hline \multirow{2}{*}{$\begin{array}{c}\text { Arufe Giráldez, } \\
\text { Sanmiguel-Rodríguez } \\
\text { et al. [32] (2020) } \\
\text { (overlapping with Arufe } \\
\text { Giráldez, Cachón } \\
\text { Zagalaz et al., [31] 2020) }\end{array}$} & - & - & - & $* *$ & * & * & - & $4 / 10$ \\
\hline & $\begin{array}{l}\text { Non-experimental } \\
\text { design for the } \\
\text { recruitment of the } \\
\text { participants }\end{array}$ & 280 & No description & Validated measurement tool & Age & Self-report & no & \\
\hline
\end{tabular}


Table A1. Cont.

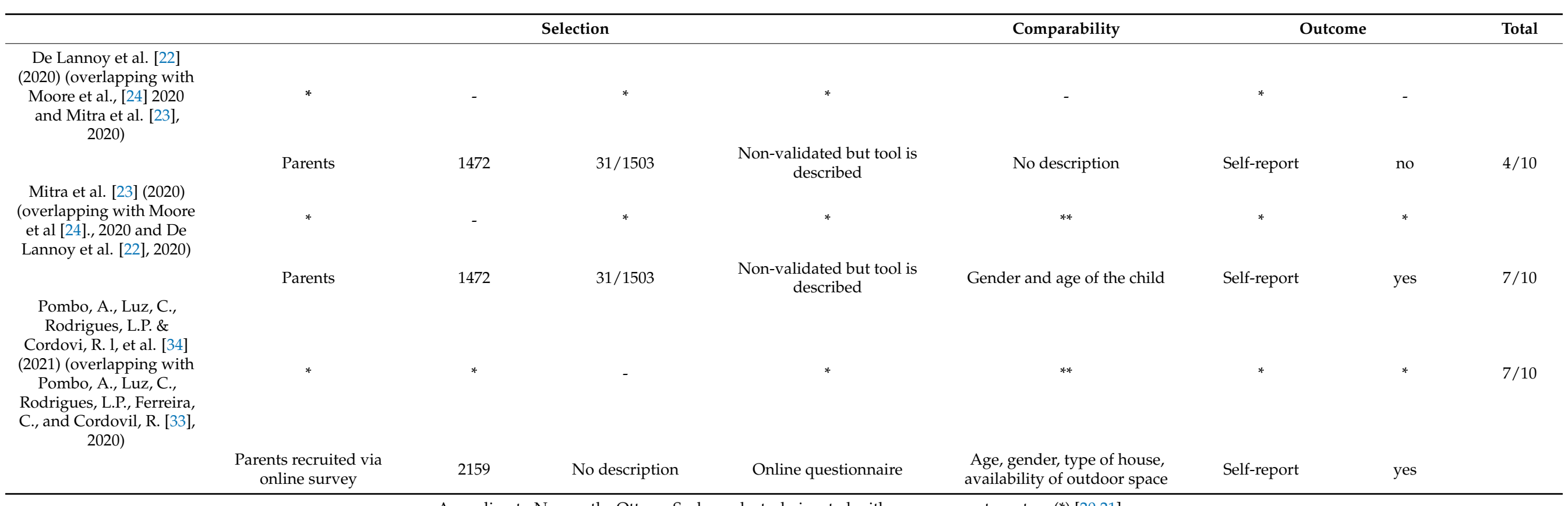

According to Newcastle-Ottawa Scale, each study is rated with none, one or two stars $\left(^{*}\right)[20,21]$. 
Table A2. Newcastle-Ottawa for Cohort Studies.

\begin{tabular}{|c|c|c|c|c|c|c|c|c|c|}
\hline & \multicolumn{4}{|c|}{ Selection } & \multirow{2}{*}{$\begin{array}{c}\text { Comparability } \\
\text { Comparability of cohorts } \\
\text { on the basis of the design } \\
\text { or analysis controlled for } \\
\text { confounders }\end{array}$} & \multicolumn{3}{|c|}{ Outcome } & \multirow[t]{2}{*}{ Total } \\
\hline First author (year) & $\begin{array}{l}\text { Representativeness } \\
\text { of the exposed } \\
\text { cohort }\end{array}$ & $\begin{array}{l}\text { Selection of the } \\
\text { non-exposed } \\
\text { cohort }\end{array}$ & $\begin{array}{l}\text { Ascertainment } \\
\text { of exposure }\end{array}$ & $\begin{array}{l}\text { Demonstration that } \\
\text { outcome of interest } \\
\text { was not present at } \\
\text { start of study }\end{array}$ & & $\begin{array}{l}\text { Assessment of } \\
\text { outcome }\end{array}$ & $\begin{array}{l}\text { Was follow-up } \\
\text { long enough for } \\
\text { outcomes to } \\
\text { occur }\end{array}$ & $\begin{array}{l}\text { Adequacy of } \\
\text { follow-up of } \\
\text { cohorts }\end{array}$ & \\
\hline \multirow[t]{2}{*}{$\begin{array}{c}\text { Medrano, } \\
\text { M. et al. [30] (2020) }\end{array}$} & * & * & * & $*$ & $* *$ & * & * & * & good quality \\
\hline & $\begin{array}{l}\text { Children and } \\
\text { adolescents in } \\
\text { Spain }\end{array}$ & Same community & MUGI project & yes & $\begin{array}{l}\text { Age, sex, school, origin } \\
\text { of mother, BMI }\end{array}$ & $\begin{array}{l}\text { Record linkage, } \\
\text { self-report }\end{array}$ & yes & no different & \\
\hline \multirow[t]{3}{*}{$\begin{array}{c}\text { Dunton GF, Do B, } \\
\text { Wang SD [26] (2020) }\end{array}$} & * & * & * & * & $* *$ & - & * & * & good quality \\
\hline & $\begin{array}{c}\text { Children } 5 \text { to } 13 \\
\text { years }\end{array}$ & Same community & $\begin{array}{l}\text { Structure } \\
\text { interview, } \\
\text { self-report }\end{array}$ & $\begin{array}{c}\text { Pre-COVID period } \\
\text { (February 20,200 } \\
\text { and early-COVID-19 } \\
\text { period (April-May } \\
\text { 2020) }\end{array}$ & $\begin{array}{l}\text { Parental age, sex, marital } \\
\text { status, work status, } \\
\text { annual household } \\
\text { income, child age, sex, } \\
\text { ethnicity, race }\end{array}$ & Self-report & yes & $\begin{array}{l}\text { Complete } \\
\text { follow-up }\end{array}$ & \\
\hline & * & * & $*$ & $*$ & & $*$ & $*$ & $*$ & \\
\hline $\begin{array}{l}\text { Giménez-Dasí, } \\
\text { M. et al. [28](2020) }\end{array}$ & $\begin{array}{l}\text { Parents of children } \\
1-10 \text { years old }\end{array}$ & Same community & Self-report & $\begin{array}{l}\text { Pre-confinement } \\
\text { (February 2020) and } \\
4-6 \text { weeks during } \\
\text { confinement }\end{array}$ & No comparability & Validated tool & yes & $\begin{array}{l}\text { Complete } \\
\text { follow-up }\end{array}$ & good quality \\
\hline
\end{tabular}

According to Newcastle-Ottawa Scale, each study is rated with none, one or two stars $\left(^{*}\right)[20,21]$. 


\section{References}

1. UN. Convention of the Rights of the Child. 1989. Available online: https://www.ohchr.org/EN/ProfessionalInterest/Pages/ CRC.aspx15/1/2021 (accessed on 28 January 2021).

2. Eberle, S. The Elements of Play toward a Philosophy and a Definition of Play. J. Play 2014, 6, $214-233$.

3. Haight, W.L.; Wang, X.-L.; Fung, H.H.; Williams, K.; Mintz, J. Universal, Developmental, and Variable Aspects of Young Children's Play: A Cross-Cultural Comparison of Pretending at Home. Child Dev. 1999, 70, 1477-1488. [CrossRef]

4. $\quad$ Jennings, S. Creative Play with Children at Risk, 2nd ed.; Routledge: Oxon, UK, 2017; pp. 16-17.

5. Garvey, C. The Developing Child Series; Play: Enlarged Edition; Harvard University Press: Cambridge, MA, USA, 1990.

6. Hurwitz, S.C. To be successful: Let them play! Child Educ. 2003, 79, 101-102.

7. Isenberg, J.; Quisenberry, N.L. Play: A necessity for all children. Child Educ. 1988, 64, 138-145. [CrossRef]

8. Barnett, L.A. Developmental benefits of play for children. J. Leis. Res. 1990, 22, 138-153. [CrossRef]

9. Erickson, R.J. Play contributes to the full emotional development of the child. Education 1985, 105, $261-263$.

10. Pellegrini, A.D.; Smith, P.K. The development of play during childhood: Forms and possible functions. Child Psychol. Psychiatry Rev. 1998, 3, 51-57. [CrossRef]

11. Flaxman, S.G. Play: An Endangered Species; Scholastic Inc.: New York, NY, USA, 1999; Volume 110, pp. $39-41$.

12. Smith, D. How play influences children's development at home and school. J. Phys. Educ. Recreat. Dance 1995, 66, 19-23. [CrossRef]

13. Band, E.B.; Weisz, J.R. How to feel better when it feels bad: Children's perspectives on coping with everyday stress. Dev. Psychol. 1988, 24, 247-253. [CrossRef]

14. National Research Council (US); Institute of Medicine (US); Committee on Integrating the Science of Early Childhood Development. From Neurons to Neighborhoods: The Science of Early Childhood Development; Shonkoff, J.P., Phillips, D.A., Eds.; National Academies Press: Washington, DC, USA, 2000.

15. Parten, M.B. Social participation among pre-school children. J. Abnorm. Soc. Psychol. 1932, 27, 243-269. [CrossRef]

16. UNESCO. Launch of "Winning Indoors" to Help Children Stay Healthy During the Covid-19 Pandemic. 2020. Available online: https:/ / en.unesco.org/news/launch-winning-indoors-help-children-stay-healthy-during-covid-19-pandemic (accessed on 15 January 2021).

17. Russell, W.; Stenning, A. Beyond active travel: Children, play and community on streets during and after the coronavirus lockdown. Cities Health 2020. Special Issue: COVID-19. [CrossRef]

18. The Atlantic. Available online: https://www.theatlantic.com/family/archive/2020/04/coronavirus-tag-and-other-games-kidsplay-during-a-pandemic/609253/ (accessed on 15 January 2021).

19. Guan, H.; Okely, A.D.; Aguilar-Farias, N.; Del Pozo Cruz, B.; Draper, C.E.; El Hamdouchi, A.; Florindo, A.A.; Jauregui, A.; Katzmarzyk, P.T.; Kontsevaya, A.; et al. Promoting healthy movement behaviours among children during the COVID-19 pandemic. Lancet Child Adolesc. Health 2020, 4, 416-418. [CrossRef]

20. Modesti, P.A.; Reboldi, G.; Cappuccio, F.P.; Agyemang, C.; Remuzzi, G.; Rapi, S.; Perruolo, E.; Parati, G.; ESH Working Group on CV Risk in Low Resource Settings. Panethnic Differences in Blood Pressure in Europe: A Systematic Review and Meta-Analysis. PLoS ONE 2016, 11, e0147601. [CrossRef] [PubMed]

21. Stang, A. Critical evaluation of the Newcastle-Ottawa scale for the assessment of the quality of nonrandomized studies in meta-analyses. Eur. J. Epidemiol. 2010, 25, 603-605. [CrossRef]

22. de Lannoy, L.; Rhode, R.; Moore, S.; Faulkner, G.; Tremblay, M. Regional differences in access to the outdoors and outdoor play of Canadian children and youth during the COVID-19 outbreak. Can. J. Public Health 2020, 111, 988-994. [CrossRef]

23. Mitra, R.; Moore, S.; Trembley, M. Healthy movement behaviours in children and youth during the COVID-19 pandemic: Exploring the role of the neighbourhood environment. Health Place 2020, 65, 102418. [CrossRef] [PubMed]

24. Moore, S.; Faulkner, G.; Rhodes, R.; Tremblay, M. Impact of the COVID-19 virus outbreak on movement and play behaviours of Canadian children and youth: A national survey. Int. J. Behav. Nutr. Phys. Act. 2020, 17, 85. [CrossRef]

25. Stienwandt, S.; Cameron, E.; Soderstrom, M.; Casar, M.; Le, C.; Roos, L. Keeping Kids Busy: Family Factors Associated with Hands-On Play and Screen Time During the COVID-19 Pandemic. PsyArXiv 2020, preprint. [CrossRef]

26. Dunton, G.; Do, B.; Wang, S. Early Effects of the COVID-19 Pandemic on Physical Activity and Sedentary Behavior in U.S. Children. BMC Public Health 2020, 20, 1351. [CrossRef] [PubMed]

27. Torres González, C.; Galindo Aldana, G.; Ibza America García León, I.A.; Padilla-López, L.A.; Alvarez Núñez, D.N.; Espinoza Gutiérrez, Y.I. COVID-19 voluntary social isolation and its effects in sociofamily and children's behavior. Salud Mental 2020, 43, 263-271. [CrossRef]

28. Giménez-Dasí, M.; Quintanilla, L.; Lucas-Molina, B.; Sarmento-Henrique, R. Six Weeks of Confinement: Psychological Effects on a Sample of Children in Early Childhood and Primary Education. Front. Psychol. 2020, 11, 590463. [CrossRef] [PubMed]

29. Martínez Muñoz, M.; Rodríguez Pascual, I.; Velásquez Crespo, G. Infancia Confinada: ¿Cómo Viven la Situación de Confinamiento Niñas, Niños y Adolescentes; Enclave de Evaluación: Madrid, Spain, 2020; pp. 110-112.

30. Medrano, M.; Cadenas-Sanchez, C.; Oses, M.; Arenaza, L.; Amasen, M.; Labayen, I. Changes in lifestyle behaviours during the COVID-19 confinement in Spanish children: A longitudinal analysis from the MUGI project. Pediatr. Obes. 2021, 16, e12731. [CrossRef] 
31. Arufe Giráldez, V.; Cachón Zagalaz, J.; Zagalaz Sánchez, M.L.; Sanmiguel-Rodríguez, A.; González Valero, G. Equipamiento y uso de Tecnologías de la Información y Comunicación (TIC) en los hogares españoles durante el periodo de confinamiento. Asociación con los hábitos sociales, estilo de vida y actividad física de los niños menores de 12 años. Rev. Latina Commun. Soc. 2020, 78, 183-204. [CrossRef]

32. Arufe-Giráldez, V.; Sanmiguel-Rodríguez, A.; Zagalaz-Sánchez, M.L.; Cachón-Zagalaz, J.; González-Valero, G. Sleep, physical activity and screens in 0-4 years Spanish children during the COVID-19 pandemic: Were the WHO recommendations met? J. Hum. Sport Exerc. 2021, 1, 1-20.

33. Pombo, A.; Luz, C.; Rodrigues, L.P.; Ferreira, C.; Cordovil, R. Correlates of children's physical activity during the COVID-19 confinement in Portugal. Public Health 2020, 189, 14-19. [CrossRef]

34. Pombo, A.; Luz, C.; Rodrigues, L.P.; Cordovil, R. COVID-19 Confinement in Portugal: Effects on the Household Routines of Children Under 13. J. Child. Fam. Stud. 2021, 30, 1664-1674. [CrossRef] [PubMed]

35. O'Keeffe, C.; McNally, S. Perspectives of early childhood teachers in Ireland on the role of play during the pandemic. PsyArXiv 2020, preprint. [CrossRef]

36. Egan, S.M.; Beatty, C.; Hoyne, C. Missing Early Education and Care during the Pandemic: The Socio-Emotional Impact of the COVID-19 Crisis on Young Children. Early Child Educ. J. 2021. Epub ahead of print.

37. Andrew, A.; Cattan, S.; Costa-Dias, M.; Sevilla, A. Family Time Use and Home Learning during the COVID-19 Lockdown; Report; Institute for Fiscal Studies: London, UK, 2020.

38. Gambin, M.; Woźniak-Prus, M.; Kmita, G. Factors related to positive experiences in parent-child relationship during the COVID19 lockdown. The role of empathy, emotion regulation, parenting self-efficacy and social support. PsyArXiv 2020. preprint. [CrossRef]

39. Armitage, R.; Nellums, L.B. Considering inequalities in the school closure response to COVID-19. Lancet Glob. Health 2020, 8, e644. [CrossRef]

40. Stavridou, A.; Stergiopoulou, A.A.; Panagouli, E.; Mesiris, G.; Thirios, A.; Mougiakos, T.; Troupis, T.; Psaltopoulou, T.; Tsolia, M.; Sergentanis, T.N.; et al. Psychosocial consequences of COVID-19 in children, adolescents and young adults: A systematic review. Psychiatry Clin. Neurosci. 2020, 74, 615-616. [CrossRef] [PubMed]

41. Graber, K.M.; Byrne, E.M.; Goodacre, E.J.; Kirby, N.; Kulkarni, K.; O' Farrelly, C.; Ramchandani, P.G. A rapid review of the impact of quarantine and restricted environments on children's play and the role of play in children's health. Child Care Health Dev. 2020, 47, 143-153. [CrossRef]

42. WHO. Age group: 5-17 years old. In Global Recommendations on Physical Activity for Health; World Health Organization: Geneva, Switzerland, 2011. Available online: https://www.who.int/dietphysicalactivity/global-PA-recs-2010.pdf (accessed on 15 March 2021).

43. Tremblay, M.S.; Gray, C.; Babcock, S.; Barnes, J.; Bradstreet, C.C.; Carr, D.; Chabot, G.; Choguette, L.; Chorney, D.; Collyer, C.; et al. Position statement on active outdoor play. Int. J. Environ. Res. Public Health 2015, 12, 6475-6505. [CrossRef] [PubMed]

44. Lasselin, J.; Alvarez-Salas, E.; Grigoleit, J. Well-being and immune response: A multi-system perspective. Curr. Opin. Pharmacol. 2016, 29, 34-41. [CrossRef] [PubMed]

45. Oosterhoff, B.; Palmer, C.A.; Wilson, J.; Shook, N. Adolescents' motivations to engage in social distancing during the COVID-19 pandemic: Associations with mental and social health. J. Adolesc. Health 2020, 67, 179-185. [CrossRef] [PubMed]

46. Brown, A. American Academy of Pediatrics Council on Communications and Media Policy Statement: Media Use by Children Younger than 2 Years. Pediatrics 2011, 128, 1040-1045. [CrossRef]

47. Dale, L.; Moore, S.; Vanderloo, L.; Faulkner, G. Physical activity and depression, anxiety, and self-esteem in children and youth: An umbrella systematic review. Ment. Health Phys. Act. 2019, 16, 66-79. [CrossRef]

48. Yogman, M.; Garner, A.; Hutchinson, J.; Hirsh-Pasek, K.; Golinkoff, R.M.; Committee on Psychosocial Aspects of Child and Family Health; Council on Communications and Media. The power of play: A pediatric role in enhancing development in young children. Pediatrics 2018, 142, e20182058. [CrossRef] [PubMed] 